\title{
EFEKTIVITAS WORKED EXAMPLE PAIRS PADA PEMBELAJARAN DAERAH PENYELESAIAN SISTEM PERTIDAKSAMAAN LINEAR DUA VARIABEL
}

\author{
The Effectiveness of Worked Example Pairs \\ on Learning the Solution Region of System of Linear Inequality in Two Variables
}

\author{
Dwi Muryanto \\ SMA Negeri 1 Wedi, Pasung, Wedi, Klaten, Jawa Tengah, Telp. (0272) 3392772, Kode Pos 57461, \\ Indonesia \\ *)E-mail korespondensi: mast4tho@gmail.com
}

\begin{abstract}
Implementation of standard mathematics learning process and subject competence can be achieved by student-centered learning. This study aims to test the effectiveness of the implementation of the worked example pairs learning strategy on the material of the solution region of system of inequality in two variables using a pre-experimental design with the intactgroup comparison paradigm. Effectiveness is seen from two perspectives, learning achievement outcomes and learning time. The study involved 35 students of class XI MIPA 1, who were randomly divided into two strategy groups. One group used the integrated worked example pairs strategy and the other group used separated worked example pairs. From the results of data processing both parametric and non-parametric, it was concluded that there was no significant difference in the average of learning achievement between the integrated worked example pairs strategy and separated worked example pairs. In addition, there was no significant difference in the mean of learning time between the integrated worked example pairs and separated worked example pairs. However, researchers tend to choose the first strategy. This is based on the consideration that even though it requires a longer learning time, the integrated worked example pairs strategy provides a higher average of learning achievement outcomes.
\end{abstract}

Keywords: cognitive load theory, mathematics, worked example pairs

\begin{abstract}
ABSTRAK
Pencapaian kompetensi serta implementasi standar proses pembelajaran matematika dapat tercapai apabila pembelajaran berorientasi pada murid. Penelitian ini bertujuan menguji keefektifan implementasi strategi belajar worked example pairs pada materi daerah penyelesaian sistem pertidaksamaan linear dua variabel menggunakan pre-experimental design dengan paradigma intact-group comparison. Keefektifan dilihat dari dua perspektif, prestasi hasil belajar dan waktu belajar. Penelitian melibatkan 35 murid kelas XI MIPA 1, yang dibagi secara acak menjadi dua kelompok strategi. Satu kelompok menggunakan strategi integrated worked example pairs dan kelompok lain menggunakan separated worked example pairs Dari hasil pengolahan data baik secara parametrik maupun non parametrik diperoleh kesimpulan bahwa tidak ada perbedaan signifikan rata-rata prestasi hasil belajar antara strategi integrated worked example pairs dengan separated worked example pairs. Selain itu tidak ditemukan pula perbedaan yang signifikan atas rata-rata waktu belajar antara strategi integrated worked example pairs dengan separated worked example pairs. Meski demikian peneliti cenderung memilih strategi pertama. Hal ini berdasarkan pertimbangan bahwa meskipun membutuhkan waktu belajar yang lebih lama, strategi integrated worked example pairs memberikan rata-rata prestasi hasil belajar yang lebih tinggi.
\end{abstract}

Kata kunci: matematika, teori beban kognitif, worked example pairs

\section{PENDAHULUAN}

Kompetensi matematika yang seharusnya dicapai oleh murid Sekolah Menengah Atas (SMA) mencakup berbagai kemampuan, diantaranya: (1) memahami konsep dan menerapkan prosedur matematika, (2) menggunakan pola sebagai dugaan dan membuat generalisasi, (3) melakukan operasi matematika, (4) melakukan penalaran matematis, (5) memecahkan masalah dan mengkomunikasikan gagasan, serta (6) menumbuhkan sikap positif seperti sikap logis dan kritis (Kemdikbud, 2018). Halhal tersebut sejalan dengan standar proses pembelajaran matematika yang dirumuskan National Council of Teachers of Mathematics yaitu: problem solving (pemecahan masalah), reasoning and proof (penalaran matematis), communication (komunikasi matematis), connection (koneksi matematis), dan representation (representasi matematis) (NCTM, 2000).

Pencapaian kompetensi matematika serta implementasi standar proses diatas akan dapat tercapai apabila pembelajaran berorientasi pada murid, yakni sebuah keadaan dimana proses pembelajaran 
memiliki karakter yang interaktif dan inspiratif, menyenangkan, menantang dan memotivasi murid untuk berpartisi aktif, serta memberikan ruang yang cukup bagi prakarsa, kreativitas dan kemandirian murid (Kemdikbud, 2016). Selain itu pembelajaran seyogyanya dilaksanakan berdasarkan pada prinsip ing ngarsa sung tuladha, ing madya mangun karsa, tutwuri andayani (memberikan contoh dan teladan ketika memimpin, saling membangun semangat dan prakarsa diantara sesama, menjadi pendukung dengan memberikan daya dan kekuatan) (Tauchid, et al., 2013).

Pembelajaran yang berorientasi pada murid sebaiknya memperhatikan optimalisasi muatan kognitif pada murid (Retnowati, 2008). Pembelajaran yang mengharuskan murid untuk memecahkan masalah secara mandiri (minimally-guided instruction) akan membawa hasil belajar yang lebih rendah dibandingkan metode-metode direct instruction (pengajaran langsung) seperti ceramah atau belajar dari contoh (Aditomo, 2009). Hal ini dapat dipahami, karena selain harus menelaah, memahami dan menaklukkan kompleksitas materi, waktu pembelajaran yang terbatas juga menjadi salah satu faktor kendala bagi murid dalam menuntaskan pembelajaran (Mufidah, 2019). Tantangan bagi murid ialah menguasai materi dalam durasi waktu pembelajaran yang terbatas.

Cognitive load theory mengelompokkan muatan kognitif menjadi tiga macam yaitu intrinsic cognitive load, extraneous cognitive load, dan germane cognitive load (Paas, Tuovinen, Tabbers, \& Van Gerven, 2010). Muatan kognitif yang ada dan bersumber dari kompleksitas materi yang sedang dipelajari disebut dengan intrinsic cognitive load. Muatan kognitif yang menghambat proses belajar disebut dengan extraneous cognitive load. Adapan muatan kognitif yang menghasilkan upaya produktif dalam mengkonstruksi pengetahuan baru disebut germane cognitive load (Mwangi \& Sweller, 1998; Sweller et al., 2011). Strategi pembelajaran yang efektif adalah strategi yang dapat mengurangi extraneous cognitive load sehingga murid dapat mengelola intrinsic cognitive load dengan baik serta mengefektifkan germane cognitive load (Ward \& Sweller, 2009). Salah satu strategi pembelajaran yang efektif ialah strategi worked example (Renkl, Atkinson, Maier, and Staley, 2002).

Strategi worked example menampilkan problem solving dengan disertai contoh langkah penyelesaian secara sistematis dan rinci sehingga dapat mengelola beban kognitif secara baik (Clark, Nguyen, dan Sweller, 2006). Pemberian contoh ini dimaksudkan untuk membantu dan menyediakan pengetahuan awal yang cukup bagi murid sehingga mampu mempelajari dengan baik materi baru yang diberikan (Sweller et al., 2011). Hasil penelitian Irwansyah \& Retnowati (2019), mendeskripsikan bahwa murid yang belajar dengan worked example mengalami cognitive load yang lebih rendah dibanding dengan murid yang belajar dengan problem solving. Hal ini menguatkan pendapat Tarmizi \& Sweller (1988) yang menyatakan worked example telah terbukti lebih baik dibandingkan dengan strategi problem solving.

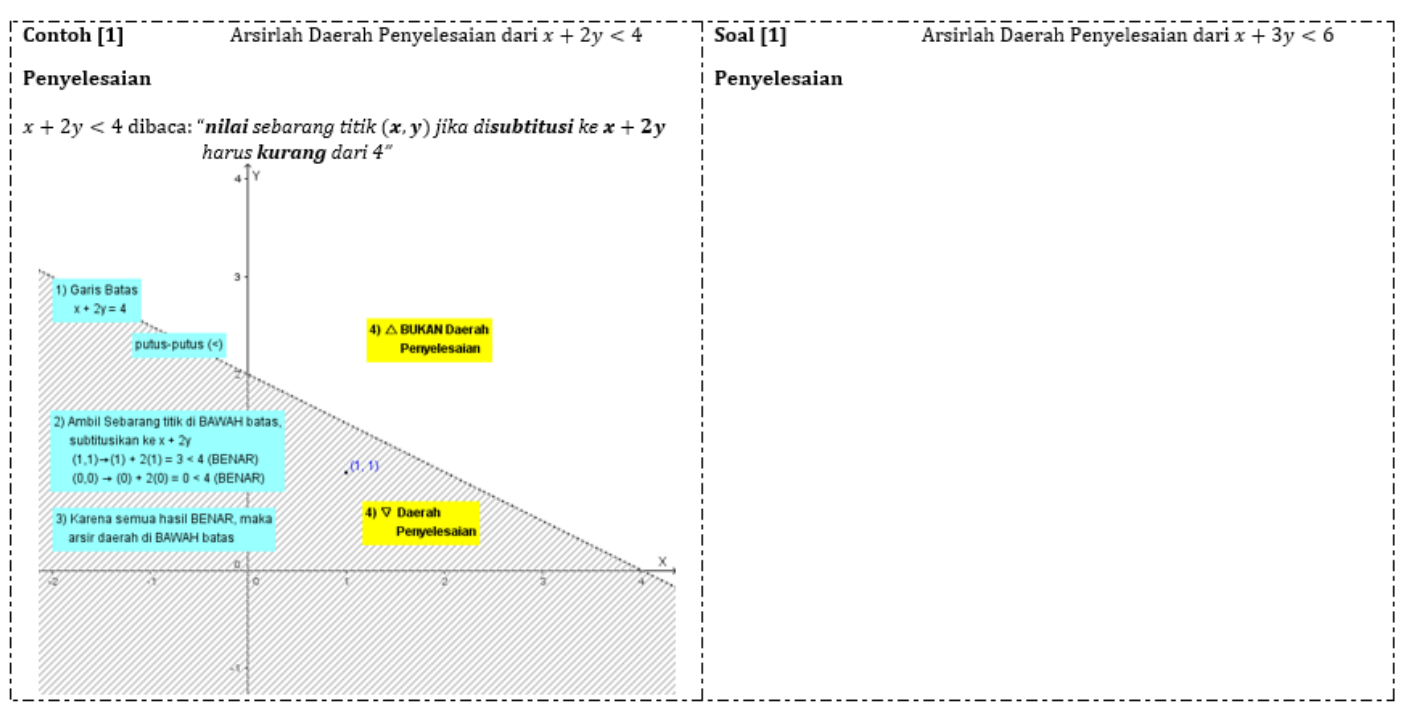

Gambar 1. Rancangan Integrated Worked Example Pairs 
Salah satu rancangan worked example ialah worked example pairs yakni pengemasan secara berurutan antara example (contoh) dengan problem (permasalahan) (Sweller \& Cooper, 1985). Sebuah rancangan dimana materi disajikan dengan cara memberikan lembar aktivitas yang berisi contoh langkah penyelesaian sebuah permasalahan dan diikuti dengan permasalahan isomorphic yang segera harus diselesaikan oleh murid (Kalyuga, Renkl, \& Paas, 2010). Permasalahan isomorphic adalah problem (permasalahan) yang memiliki solusi identik dengan example (contoh), namun direpresentasikan secara berbeda (Reed, 2011).

Pada materi daerah penyelesaian pertidaksamaan linear dua variabel, worked example pairs ini dapat ditampilkan dengan dua macam desain, terpadu (integrated) dan terpisah (separated). Desain desain Integrated Worked Example Pairs (IWEP), sebagaimana gambar 1, langkah pengerjaan dan solusi akhir permasalahan ditampilkan secara terintegrasi pada satu bagian. Adapun Separated Worked Example Pairs (SWEP) sebagaimana gambar 2, merupakan sebuah desain, dimana langkah pengerjaan disajikan pada bagian terpisah dari solusi akhir permasalahan.

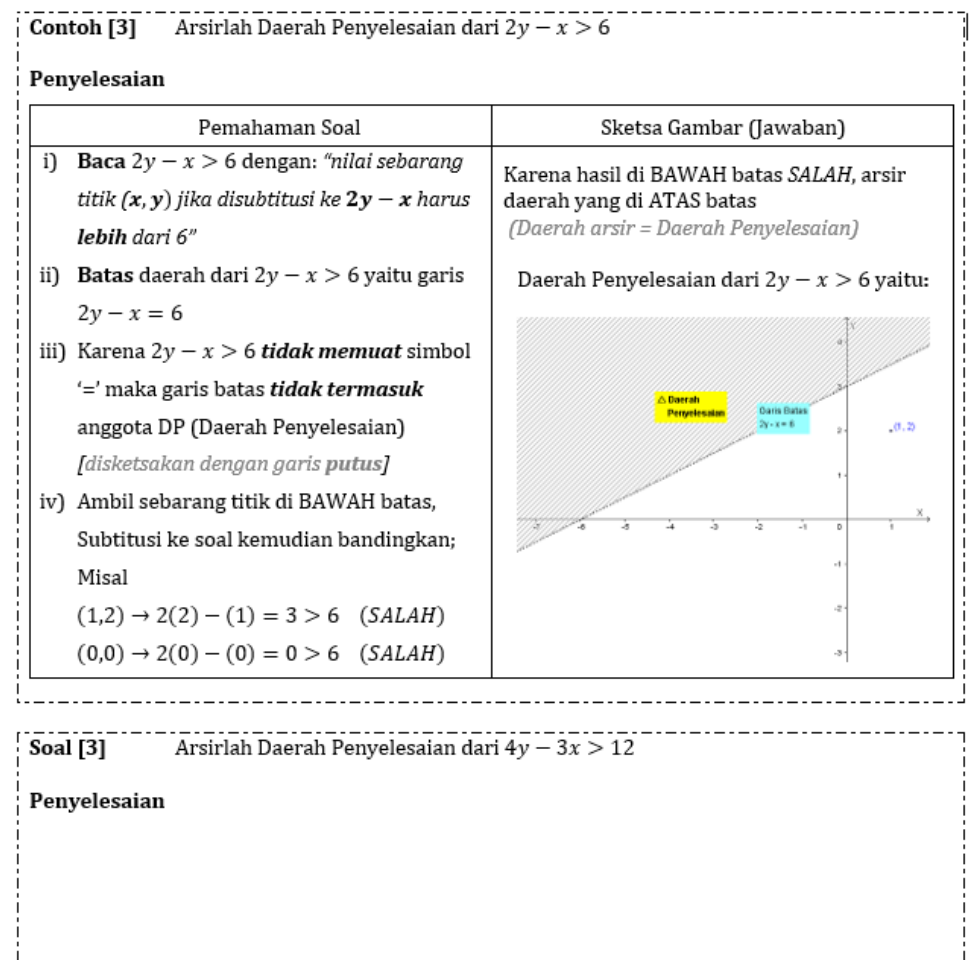

Gambar 2. Rancangan Separated Worked Example Pairs

Oleh karena worked example pairs ini merupakan hal yang baru di lingkungan kerja penulis, maka diperlukan sebuah penelitian atau uji coba terbatas guna memperoleh data dan fakta keefektifan dari kedua desain tersebut. Keefektifan dilihat dari sudut pandang hasil prestasi belajar dan waktu belajar. Adapun materi pembelajaran yang disampaikan yaitu daerah sistem pertidaksamaan linear dua variabel. Manfaat akhir yang hendak dicapai dari penelitian ini ialah agar murid dapat menguasai materi daerah sistem pertidaksamaan linear dua variabel dalam durasi pembelajaran yang terbatas.

\section{METODE}

Desain penelitian menggunakan Pre-experimental design dimana hasil eksperimen bukan sematamata dipengaruhi oleh variabel independen. Hal ini terjadi oleh karena tidak adanya variabel kontrol serta sample tidak dipilih secara random atau telah ditentukan. Model penelitiannya menggunakan intact-group comparison yakni paradigma penelitian dimana sampel dikelompokkan dalam dua grup, kemudian diberikan treatment/perlakuan yang berbeda untuk masing-masing grup kemudian diobservasi dan dibandingkan hasilnya (Sugiyono, 2014). 
Dua variabel bebas pada penelitian ini yaitu: penggunaan strategi integrated worked examples pairs dan separated worked example pairs. Adapun variabel yang diobservasi (variabel terikat) pada penelitian ini yaitu prestasi hasil belajar dan waktu belajar.

Prestasi hasil belajar diperoleh dari akumulasi skor hasil pekerjaan murid. Terdapat 5 butir worked example yang harus dipelajari dan diselesaikan dimana masing-masing butir memiliki skor maksimal 5. Sehingga apabila seorang murid sempurna benar mengerjakan 5 butir worked example tersebut, ia akan mendapatkan total skor 25. Gambar 3 berikut ini hanya menampilkan kumpulan problem (permasalahan) dalam worked example dimaksud.

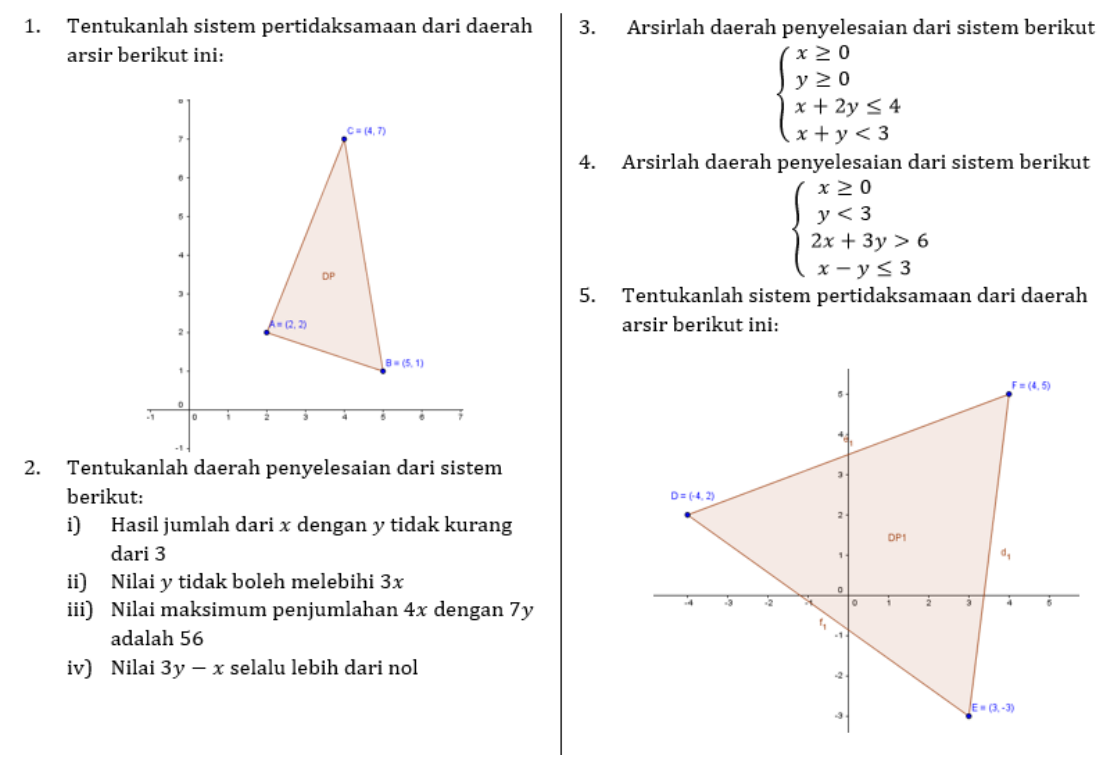

Gambar 3. Problem (permasalahan) yang diajukan dalam penelitian

Adapun yang dimaksud waktu belajar ialah waktu yang dibutuhkan murid untuk menyelesaikan 5 butir worked example yang diberikan, termasuk didalamnya waktu pengecekan ulang (looking back). Secara sederhana, waktu belajar ialah waktu yang dibutuhkan murid, sedari awal mulai mempelajari contoh, mengerjakan soal hingga siap mengumpulkan jawaban.

Kelas XI MIPA 1 ditentukan sebagai kelas eksperimen. Penelitian dilaksanakan pada semester gasal tahun 2019/2020. Banyaknya subjek penelitian sebanyak 35 Murid, yang dikelompokkan secara random menjadi dua kelompok, yakni kelompok integrated worked examples pairs (IWEP) dan separated worked example pairs (SWEP).

Teknis randomisasi kelompok dilakukan dengan memberikan lembar aktivitas secara selang seling. Murid yang mendapatkan lembar aktivitas dengan desain sebagaimana gambar 1 menjadi kelompok $I W E P$. Adapan murid yang mendapatkan lembar aktivitas dengan desain sebagaimana gambar 2 menjadi kelompok SWEP. Materi yang disajikan sama untuk kedua kelompok yakni daerah sistem pertidaksamaan linear dua variabel.

Hipotesis awal yang dibangun pada variabel prestasi hasil belajar yakni tidak terdapat perbedaan prestasi hasil belajar yang signifikan antara murid yang menggunakan strategi integrated worked example pairs dengan separated worked example pairs. Sedangkan hipotesis alternatifnya yaitu terdapat perbedaan prestasi hasil belajar yang signifikan antara murid yang menggunakan strategi integrated worked example pairs dengan separated worked example pairs.

Adapun hipotesis awal yang dibangun pada variabel waktu belajar yakni tidak terdapat perbedaan waktu belajar yang signifikan antara strategi integrated worked example pairs dengan separated worked example pairs. Sedangkan hipotesis alternatifnya yaitu terdapat perbedaan waktu belajar yang signifikan antara strategi integrated worked example pairs dengan separated worked example pairs. 
Teknik pengumpulan data yang digunakan dalam penelitian ini yaitu tes dan non-tes. Teknik tes digunakan untuk mengetahui prestasi hasil belajar murid, sedangkan teknik non tes digunakan untuk mengetahui waktu belajar.

Sedangkan teknik analisa data menggunakan uji T-Test; menggunakan Lavene's Test dan MannWhitney Test, dengan mengambil taraf signifikansi $95 \%$.

\section{HASIL DAN PEMBAHASAN}

Observasi dan pengambilan data pada penelitian ini dilaksanakan saat pembelajaran matematika berlangsung sebagaimana jadwal pembelajaran yang biasa murid ikuti. Dengan demikian, dapat dipastikan tidak terdapat persiapan khusus yang dilakukan murid. Selain itu, pengelompokan murid dalam dua kelompok strategi juga dilakukan secara acak. Hal ini dilakukan agar diperoleh data yang valid dan reliabel.

Banyaknya murid yang terdaftar ada 36 anak, namun pada saat observasi dan pengambilan data terdapat seorang murid yang tidak hadir. Dengan demikian subjek penelitian ini hanya sebanyak 35 murid. Adapun randomisasi kelompok menghasilkan 17 murid menggunakan strategi integrated worked example pairs sedangkan 18 murid menggunakan strategi separated worked example pairs.

\section{Uji Parametrik}

Setelah data terkumpul, kemudian dilakukan analisa dengan melakukan uji perbandingan rata-rata variabel pada kedua kelompok strategi. Pada mulanya, digunakan teknik statistika parametrik, yakni dengan menggunakan Lavene's Test. Hasil uji statistiknya dapat dilihat pada uraian berikut ini:

\section{Uji Parametrik Variabel Prestasi Hasil Belajar}

Tabel 1: Statistika Deskriptif Grup

\begin{tabular}{lllll}
\hline Kelompok & Banyaknya & Rata-Rata & St. Dev & SEM \\
\hline IWEP & 17 & 18.5882 & 8.66068 & 2.10052 \\
\hline SWEP & 18 & 17.111 & 7.2183 & 1.70138 \\
\hline
\end{tabular}

Dari tabel dapat dilihat bahwa skor rata-rata hasil prestasi belajar kelompok Integrated Worked Example Pairs lebih tinggi dibandingkan dengan Separated Worked Example Pairs. Meski demikian, belum tentu hal ini menunjukkan adanya perbedaan yang signifikan.

Tabel 2: Hasil Lavene's Test

\begin{tabular}{llllll}
\hline & $\mathrm{F}$ & Sig. & T & Df & Sig.(2-tailed) \\
\hline Equal variances assumed & 1.469 & 0.234 & -0.549 & 33 & 0.586 \\
\hline Equal variances not assumed & & & -0.546 & 31.230 & 0.589 \\
\hline
\end{tabular}

Nilai sig. Lavene's Test for Equality of Variances 0,234 > 0.05 memiliki arti varians data strategi integrated worked example pairs dengan separated worked example pairs adalah homogen atau sama. Selanjutnya oleh karena Nilai sig. (2-tailed) pada baris Equal variances assumed sama dengan $0.586>0.05$ maka hipotesa awal diterima dan hipotesa alternatif ditolak. Hal ini menunjukkan arti bahwa tidak ada perbedaan yang signifikan rata-rata hasil prestasi belajar antara strategi integrated worked example pairs dengan separated worked example pairs.

\section{Uji Parametrik Variabel Waktu Pengerjaan}

Waktu belajar ialah waktu yang dibutuhkan murid, sedari awal mulai mempelajari contoh, mengerjakan soal hingga siap mengumpulkan jawaban. Satuan yang digunakan pada waktu belajar ini adalah menit. Tabel-tabel berikut merupakan hasil uji statistiknya.

Tabel 3: Statistika Deskriptif Grup

\begin{tabular}{lllll}
\hline Kelompok & Banyaknya & Rata-Rata & St. Dev & SEM \\
\hline$I W E P$ & 17 & 20.3265 & 7.17160 & 1.73937 \\
\hline SWEP & 18 & 17.3022 & 7.03507 & 1.65818 \\
\hline
\end{tabular}


Dapat dilihat bahwa waktu belajar yang dibutuhkan murid-murid yang menggunakan strategi Integrated Worked Example Pairs lebih lama lebih kurang 3 menit dibandingkan dengan waktu yang dibutuhkan murid dengan strategi Separated Worked Example Pairs. Namun, diperlukan uji lanjutan untuk menunjukkan adanya perbedaan yang signifikan.

Tabel 4: Hasil Lavene's Test Variabel Waktu Belajar

\begin{tabular}{llllll}
\hline & $\mathrm{F}$ & Sig. & $\mathrm{T}$ & $\mathrm{Df}$ & Sig.(2-tailed) \\
\hline Equal variances assumed & 0.002 & 0.961 & -1.259 & 33 & 0.217 \\
\hline Equal variances not assumed & & & -1.258 & 32.800 & 0.217 \\
\hline
\end{tabular}

Nilai sig. Lavene's Test for Equality of Variances $0.961>0.05$ memiliki arti varians data strategi integrated worked example pairs dengan separated worked example pairs adalah homogen atau sama. Selanjutnya oleh karena Nilai sig. (2-tailed) pada baris Equal variances assumed sama dengan $0.217>0.05$ maka disimpulkan tidak ada perbedaan yang signifikan rata-rata waktu belajar antara strategi integrated worked example pairs dengan separated worked example pairs.

\section{Uji Non Parametrik}

Setelah dilakukan uji parametrik, dan ternyata tidak ditemukan perbedaaan yang signifikan antara strategi integrated worked example pairs dengan separated worked example pairs baik ditinjau dari prestasi hasil belajar maupun dari waktu belajar maka diputuskan untuk melakukan uji tambahan, yakni dengan uji non parametrik. Hal ini mengingat bahwa subjek penelitian yang hanya 35 murid secara jumlah belumlah ideal. Untuk itu dilakukanlah Mann-Whitney Test.

\section{Uji Non-Parametrik Variabel Prestasi Hasil Belajar}

Hasil uji non-parametrik atas variabel hasil prestasi belajar dapat dilihat pada uraian di bawah ini.

Tabel 5: Hasil Mann-Whitney Test

\begin{tabular}{ll}
\hline & Nilai \\
\hline Mean Separated Worked Example Pairs & 16.97 \\
\hline Mean Integrated Worked Example Pairs & 19.09 \\
\hline Mann-Whitney U & 134.500 \\
\hline Wilcoxon W & 305.500 \\
\hline Z & -0.614 \\
\hline Asymp. Sig. (2-tailed) & 0.539
\end{tabular}

Dari tabel diatas, nilai Asymp. Sig. (2-tailed) prestasi hasil belajar murid yakni sebesar $0.539>0.05$ yang artinya tidak ada perbedaan yang signifikan rata-rata hasil prestasi belajar antara strategi integrated worked example pairs dengan separated worked example pairs.

\section{Uji Non-Parametrik Variabel Waktu Belajar}

Hasil uji non-parametrik atas variabel waktu belajar dapat dilihat pada uraian berikut.

Tabel 6: Hasil Mann-Whitney Test Waktu Belajar

\begin{tabular}{ll}
\hline & Nilai \\
\hline Mean Separated Worked Example Pairs & 15.39 \\
\hline Mean Integrated Worked Example Pairs & 20.76 \\
\hline Mann-Whitney U & 106.000 \\
\hline Wilcoxon W & 277.000 \\
\hline Z & -1.551 \\
\hline Asymp. Sig. (2-tailed) & 0.121 \\
\hline
\end{tabular}

Ternyata nilai Asymp. Sig. (2-tailed) waktu belajar murid sebesar $0.121>0.05$. Hal ini dapat disimpulkan bahwa tidak ada perbedaan yang signifikan rata-rata waktu pengerjaan antara strategi integrated worked example pairs dengan separated worked example pairs. 


\section{Pembahasan}

Hasil penelitian menunjukkan bahwa efektivitas pembelajaran dengan strategi integrated worked example relatif sama dengan strategi separated worked example pairs baik ditinjau dari prestasi hasil belajar maupun waktu belajar. Rata-rata nilai prestasi hasil belajar kelompok dengan strategi integrated worked example ternyata lebih tinggi dibandingkan dengan rata-rata nilai prestasi belajar kelompok dengan strategi separated worked example pairs, namun hal ini tidak menunjukkan adanya perbedaan keefektifan yang signifikan antara kedua strategi tersebut.

Tidak ditemukannya perbedaan keefektifan dari kedua desain ini disebabkan selama pembelajaran, murid diharuskan belajar secara individual, tidak berkolaborasi, sehingga murid tidak memiliki partner untuk berdiskusi. Pada momen awal, saat murid menerima lembar aktivitas worked example pairs, beberapa murid mengajukan pertanyaan yang sama, untuk alasan apa model pembelajaran ini dilaksanakan karena hal ini di luar kebiasaan dalam pembelajaran. Hal ini mengindikasikan bahwa strategi ini merupakan hal baru bagi murid, sehingga murid tidak terbiasa dengan strategi ini. Fenomena ini sesuai dengan apa yang dikemukakan Irwansyah \& Retnowati (2019), dimana adaptasi murid terhadap strategi worked example berimbas pada keefektifan strategi tersebut. Pertanyaan dari murid, adaptasi dan pembiasaan murid terhadap strategi worked example pairs ini pada akhirnya berimbas pada waktu belajar yang menjadi tidak berbeda secara signifikan.

Meskipun pembelajaran kolaboratif tidak lebih efektif dibandingkan dengan pembelajaran individual ditinjau dari kemampuan pemecahan masalah (Irwansyah \& Retnowati, 2019), penelitian ini masih dapat dikembangkan dengan memadukan strategi worked example pairs dengan kolaborasi. Melalui strategi worked example kemandirian belajar murid dapat meningkat (Mufidah, 2019) adapun melalui kolaborasi murid memiliki kesempatan yang sama dalam membantu murid lainnya sehingga terjadi interaksi positif di lingkungan belajar para murid (Retnowati, 2012).

Ada pula efek dari implementasi worked example yang akan meningkatkan extraneous cognitive load sehingga sama-sama mengurangi efektivitas pembelajaran yakni split-attention dan redundancy effects ini (Retnowati, 2014). Efek split-attention muncul akibat penyajian informasi dilakukan secara terpisah, sedang efek redundance muncul sebagi akibat tumpang tindih informasi (Sweller et al., 2011). Kedua efek ini, belum diperhitungkan dan tidak menjadi perhatian dalam penelitian ini, sehingga menjadi variabel luar yang belum terkontrol dan mempengaruhi keefektifan kedua strategi pembelajaran yang diimplementasikan dalam penelitian.

Meski hasil akhir penelitian menunjukkan tidak adanya perbedaan yang signifikan antara strategi integrated worked example pairs dengan separated worked example pairs dilihat dari prestasi hasil belajar dan waktu belajar, namun peneliti cenderung memilih strategi pertama. Hal ini berdasarkan pertimbangan bahwa meskipun membutuhkan waktu belajar yang lebih lama, strategi integrated worked example pairs memberikan rata-rata prestasi hasil belajar yang lebih tinggi.

\section{KESIMPULAN DAN SARAN.}

\section{Kesimpulan}

1. Tidak ada perbedaan signifikan atas rata-rata hasil prestasi belajar antara strategi integrated worked example pairs dengan separated worked example pairs.

2. Tidak ditemukan pula perbedaan yang signifikan atas rata-rata waktu belajar antara strategi integrated worked example pairs dengan separated worked example pairs.

3. Peneliti memilih strategi integrated worked example pairs untuk diimplementasikan dalam pembelajaran berikutnya. Hal ini berdasarkan pertimbangan bahwa meskipun membutuhkan waktu belajar yang lebih lama, strategi integrated worked example pairs memberikan rata-rata prestasi hasil belajar yang lebih tinggi.

\section{Saran}

1. Murid perlu dibiasakan menggunakan strategi worked example pairs dalam pembelajaran, sehingga matang dan terbiasa dengan strategi tersebut. Dengan demikian validitas instrumen dapat ditingkatkan. 
2. Strategi worked example pairs ini, dapat diimplementasikan dengan memvariasi model pembelajaran salah satunya dengan kerja kelompok (kolaborasi). Melalui kolaborasi diharapkan beban kognitif yang dialami murid ketika belajar matematika dapat dikurangi sehingga efektifitas strategi pembelajaran dapat ditingkatkan.

3. Diperlukan desain lain yang berbeda dengan desain pre-experimental, misalnya dengan Penelitian Tindakan Kelas sehingga variabel luar yang masih berpengaruh dan sulit dikontrol dapat diminimalisir.

4. Perbedaan keefektifan kedua desain worked example pairs dapat diteliti ulang dengan memperbanyak jumlah sampel.

\section{DAFTAR PUSTAKA}

Aditomo, A. (2009). Cognitive Load Theory and Mathematics Learning: A Systematic Review. Anima, Indonesian Psychological Journal, 24(3), 207-217.

Clark, R., Nguyen, F., \& Sweller, J. (2006). Efficiency in learning: evidence based guidelines to manage cognitive load. San Francisco, CA: Pfeiffer.

Irwansyah, M. F., \& Retnowati, E. (2019). Efektivitas worked example dengan strategi pengelompokan siswa ditinjau dari kemampuan pemecahan masalah dan cognitive load. Jurnal Riset Pendidikan Matematika, 6(1), 62-74.

Kalyuga, S., Renkl, A., \& Paas, F. G. (2010). Facilitating flexible problem solving: A cognitive load perspective. Educational psychology review, 175-186.

Kemendikbud. (2016). Permendikbud No. 22 tentang Standar Proses Pendidikan Dasar dan Menengah. Jakarta: Kemendikbud.

Kemendikbud. (2016). Permendikbud No. 24 tentang kompetensi inti dan kompetensi dasar. Jakarta: Kemendikbud.

Kemdikbud. (2018). Permendikbud No. 37 tentang perubahan atas permendikbud no. 24 tahun 2016 tentang kompetensi inti dan kompetensi dasar. Jakarta: Kemdikbud.

Mufidah, S. (2019). Upaya meningkatkan kemandirian belajar siswa dalam pembelajaran matematika menggunakan worked example pada siswa kelas VIII J SMP Negeri 5 Yogyakarta tahun pelajaran 2018/2019. Prosiding Sendika, Vol. 5, No. 1, 2019, 346351 .

Mwangi, W., \& Sweller, J. (1998). Learning to solve compare word problems: The effectof example format and generating self-explanations. Cognition and Instruction, 16(2), 173-199.

National Council of Teachers of Mathematics. (2000). Principles and standards for school mathematics. VA: author.

Paas, F., Touvinen, J. E., Tabbers, H., \& Van Gerven, W. M. (2010). Cognitive load measurement as a means to advance cognitive load theory. Education Psychologist, $38(1), 63-71$.

Reed, S. K. (2011). Kognisi: teori dan aplikasi. Jakarta: Salemba Humanika.

Renkl, A., Atkinson, R., Maier, U., \& Staley, R. (2002). From example study to problem solving: smooth transition help learning. The Journal of Experimental Education, 293315.

Retnowati, E. (2008). Keterbatasan memori dan implikasinya dalam mendesain metode pembelajaran. Semnas Matematika dan Pendidikan Matematika, 24-27 November 2008. (hal. 2-359-372). Yogyakarta: Universitas Negeri Yogyakarta.

Retnowati, E. (2012, November). Worked examples in mathematics. In 2nd International STEM in Education Conference (pp. 393-395)

Retnowati, E. (2014). Psychology of mathematics learning: Constructing knowledge. Yogyakarta: UNY.

Sugiyono. (2014). Metode penelitian kuantitatif, kualitatif dan R\&D. Bandung: Alfabeta. 
Sweller, J., Ayres, P., \& Kalyuga, S. (2011). Cognitive load theory: explorations in the learning science, instructional systems and performance technologies. New York: Springer.

Sweller, J., \& Cooper, G.A. (1985). The use of worked examples as a substitute for problem solving in learning algebra. Cognition and Instruction, 2(1), 59-89.

Tarmizi, R. A., \& Sweller, J. (1988). Guidence during mathematical problem solving. Journal of Eductional Psychology, 80(4), 424-436.

Tauchid, M., Soeratman, Sajoga, Lahade, R. S., Soendoro, \& Surjohadidjojo. (2013). Ki hadjar dewantara, bagian pertama: pendidikan. Yogyakarta: UST-Press.

Ward, M., \& Sweller, J. (2009). Structuring effective worked examples. Cognitive and Instruction, 7(1), 1-39. 